\title{
Characteristics of Neonates with Hyperbilirubinemia in Cileunyi, West Java
}

\author{
Muhammad Rizki Fonna, ${ }^{1}$ Nia Kania, ${ }^{2}$ Gita Tiara Dewi Nasution ${ }^{2}$ \\ ${ }^{1}$ Faculty of Medicine Universitas Padjadjaran, Indonesia, ${ }^{2}$ Department of Biomedical Sciences \\ Faculty of Medicine Universitas Padjadjaran, Indonesia
}

\section{Abstract}

Background: Neonates are prone to hyperbilirubinemia or jaundice due to the immaturity of various organ systems and complications at birth. Immature organ systems occur primarily in preterm babies and babies with low birth weight (LBW). The incidence of hyperbilirubinemia is about $60 \%$ among term neonates and is higher in preterm neonates. This study aimed to determine the characteristics of neonates with hyperbilirubinemia.

Methods: This study used a cross sectional research design. Samples were obtained from medical records of neonates with hyperbilirubinemia throughout 2019 at Annisa Medical Center Hospital, Bandung Regency. Data on neonates that met the inclusion criteria were selected, including gender, gestational age, birth weight, mode of delivery, bilirubin levels (before and after phototherapy), and duration of treatment. Data analysis was performed using univariate statistical calculations.

Results: From 786 data obtained, the prevalence rate of hyperbilirubinemia was 21.2\%. Male neonates with hyperbilirubinemia were predominantly prevalent $(n=103 ; 61.7 \%)$; whereas preterm neonates accounted for $51.5 \%(\mathrm{n}=86)$, normal weight $(85.6 \%)$, and born through vaginal delivery $(n=116 ; 69.5 \%)$. After treatment, total bilirubin levels decreased, with the percentage of the $>10$ $\mathrm{mg} / \mathrm{dl}$ group decreasing from $97.0 \%$ to $10.2 \%$. The average duration of treatment for neonates with hyperbilirubinemia was 4.4 days, however, the neonates who were treated less than the average were $71.3 \%$

Conclusions: Preterm male is predominantly prevalent among neonates with hyperbilirubinemia, although they have conformed birth weight and vaginal delivery mode. The duration of treatment for neonates with hyperbilirubinemia mostly does not exceed 4 days, as long as the treatment reduces the total bilirubin level. Good therapeutic management in the first week of hyperbilirubinemia neonates is required.

Keywords: Characteristics, hyperbilirubinemia, neonates

\section{Introduction}

Hyperbilirubinemia, also known as jaundice, is a clinical condition in babies characterized by yellowish skin and sclera due to increased serum bilirubin levels. ${ }^{1}$ The majority of jaundice is generally classified as physiological, however, the rest still have a potential to become pathological with a higher risk of various complications. Therefore, the incidence of jaundice needs attention. ${ }^{2}$ The prevalence of babies with hyperbilirubinemia in the United States 3 is $65 \%$, in Nigeria ${ }^{4} 33 \%$, and in Malaysia $^{5} 75 \%$. In Indonesia, the incidence of jaundice in term babies, especially in West Java Province, is ranging from $10.4 \%$ to $85 \%{ }^{3,6}$

Causes of hyperbillirubinemia are considered to be predisposing factor, and common causes include maternal, perinatal and neonatal factors. ${ }^{7}$ These causes are also influenced by several risk factors, such as preterm babies $(<37$ weeks), babies with low birth weight (LBW), and the mode of delivery. ${ }^{8}$ Jaundice is a problem in neonates that is often faced by health professionals, which occurs in about $60 \%$ of term neonates and is even higher in preterm neonates. ${ }^{6}$ Therefore, the

Correspondence: Muhammad Rizki Fonna, Faculty of Medicine Universitas Padjadjaran, Jalan Raya Bandung Sumedang Km. 21 Jatinangor, Sumedang Indonesia, E-mail: muhammad17349@mail.unpad.ac.id 
examination of jaundice in neonates should be carried out at the time of the neonatal visit or when examining the babies at the clinic. ${ }^{6}$ This problem is related to the Neonatal Mortality Rate (NMR) in Indonesia of 15 deaths per 1000 births in 2017, which is relatively high, 9 compared to the World Health Organization (WHO) sustainable developments target of 12 deaths per 1000 births. ${ }^{10}$

Considering that there are still many neonates who experience hyperbilirubinemia, including in West Java and Bandung Regency, this study aimed to explore the characteristics of neonates suffering from hyperbilirubinemia at Annisa Medical Center (AMC) Hospital Bandung Regency.

\section{Methods}

The research was a descriptive study, involving data on neonates with hyperbilirubinemia recorded at the Annisa Medical Center (AMC) Hospital Bandung Regency in 2019. Data on gender, gestational age, birth weight, mode of delivery, total bilirubin levels, and duration of treatment were noted. This research obtained permission from the Ethics Committee of
Universitas Padjadjaran with the number 1066/UN6.KEP/EC/2020.

The data was further explored using the Microsoft Office Excel program, and the univariate method was conducted to determine the characteristics of neonates with hyperbilirubinemia according to the variables reviewed. The data were then presented in frequency.

\section{Results}

In total, 786 neonates were recorded, of which 167 had hyperbilirubinemia, thus the prevalence rate of neonates with hyperbilirubinemia at AMC Hospital Bandung Regency was $21.2 \%$. Male neonates were the most prevalent neonates $(61.7 \%)$ with hyperbilirubinemia. Furthermore, $51.5 \%$ of the neonates were preterm although most had normal birth weight based on gestastional age $(85.6 \%)$. Most of the neonates were born by normal vaginal delivery.

Based on total bilirubin levels, most of the neonates had lower total bilirubin level after treatment and most of them were hospitalized for less or equal to 4 days as shown in Table.

Table Characteristics of Neonates with Hyperbilirubinemia $(n=167)$ Registered at AMC Hospital Bandung Regency in 2019

\begin{tabular}{lcc}
\hline \multicolumn{1}{c}{ Characteristics } & $\mathbf{n}$ & $\mathbf{\%}$ \\
\hline Gender & & \\
$\quad$ Male & 103 & 61.7 \\
Female & 64 & 38.3 \\
Gestational Age & & \\
$\quad$ Full term & 81 & 48.5 \\
$\quad$ Preterm & 86 & 51.5 \\
Birth Weight & & \\
$\quad$ Normal & 143 & 85.6 \\
$\quad$ Low & 21 & 12.6 \\
$\quad$ Very Low & 3 & 1.8 \\
Mode of Delivery & & \\
$\quad$ Cesarean section & 51 & 30.5 \\
$\quad$ Vaginal Delivery & 116 & 69.5 \\
Total Bilirubin Level (mg/dl) & & \\
$\quad$ Before Treatment & & 3.0 \\
$\quad<10$ & 5 & 97.0 \\
$\quad$ After Treatment & 162 & 89.8 \\
$\quad<10$ & 150 & 10.2 \\
$\quad>10$ & 17 & 71.3 \\
Treatment Duration (days) & & 28.7 \\
$\quad<4$ & 119 & \\
$\quad>4$ & 48 &
\end{tabular}


When all neonates were included, the percentage of neonates with normal birth weight who experienced hyperbilirubinemia was $20.6 \%$. Low birth weight neonates who had hyperbilirubinemia were $24.7 \%$, whereas very low birth weight neonates who had hyperbilirubinemia were $50.0 \%$. Similarly for the mode of delivery, the percentage of neonates born by cesarean section who experienced hyperbilirubinemia was $22.9 \%$ and through vaginal delivery was $20.6 \%$ (data not shown).

\section{Discussions}

The prevalence rate of neonates with hyperbilirubinaemia in this study was $21.2 \%$, and compared to the Cileunyi area and its surrounding in East Bandung, this number is still relatively high. ${ }^{11}$ Male neonates were predominantly prevalent $(61.7 \%)$, similar to another study conducted previously at a tertiary hosiptal in Bandung. ${ }^{11}$ However, the effect of gender on the increase in bilirubin levels is still unclear. Factors that are thought to influence the metabolism of bilirubin in male babies are the Y chromosome which causes increased metabolism and deficiency of enzyme system maturation in the formation, metabolism, and elimination of serum bilirubin. ${ }^{6}$

The percentage of preterm neonates with hyperbilirubinemia was 51.5\%. Preterm neonates are more prone to hyperbilirubinemia than term neonates. ${ }^{12}$ This might be related to organ immaturity in premature babies, which causes physiological functions to not work properly. The low activity of the enzyme uridine diphosphate glucuronyl transferase (UDPGT) causes a low ability to conjugate bilirubin in neonates. Moreover, the short lifespan of red blood cells in neonates leads to an increase in the hemolysis process, which results in an increase in unconjugated bilirubin. ${ }^{12}$

Furthermore, there is a higher risk for immaturity of the hepatic organs in neonates with low birth weight leading to low excretion of bilirubin,leading to increased bilirubin levels in the blood. ${ }^{12}$ Interestingly, our study showed that the majority of neonates $(85.6 \%)$ with normal birth weight had hyperbilirubinemia, similar to other studies which showed that the percentage of neonates with normal birth weight tended to be high. ${ }^{13-15}$ These results contradict the previously mentioned hypothesis. ${ }^{12}$ The number of patients might limit the statistical analysis, therefore, further studies with a larger number of neonates should be performed.

Moreover, most of neonates with hyperbilirubinemia were born through normal vaginal delivery, similar to the study in Yogyakarta. ${ }^{16}$ However, in another place in Bogor, West Java, half of the neonates with hyperbilirubinemia were born by assisted abnormal birth mode delivery and cesarean section. ${ }^{17}$ The study explains that it may be due to the possibility of various complications during delivery through the procedure. ${ }^{7}$

In this study, before treatment, $97 \%$ of neonates with hyperbilirubinemia had a total bilirubin level of $>10 \mathrm{mg} / \mathrm{dl}$, which decreased after treatment. However, $10.2 \%$ still has a high level. After 24 hours of treatment, preterm neonates decreased by $2.25 \mathrm{mg} / \mathrm{dl}$, whereas term neonates by $2.6 \mathrm{mg} / \mathrm{dl}^{3}{ }^{3}$ Interestingly, another study showed that the average total bilirubin level after phototherapy treatment decreased by $4.64 \mathrm{mg} / \mathrm{dL}$, whereas if additional massage therapy or field massage was applied, the average total bilirubin level decreased further by $7.17 \mathrm{mg} / \mathrm{dl}^{18}$ These results indicate that treatment given to neonates with hyperbilirubinemia is effective in reducing bilirubin levels; the closer phototherapy is to the body, the more effective it is..$^{19}$ In addition, another study reported that there was no significant difference in phototherapy position in either the supine position or position change because the number of areas treated with phototherapy was the same despite the change in position. ${ }^{20}$ In this study, neonates with hyperbilirubinemia have been treated an average of 4.4 days (range 2-21 days). However, most of the neonates $(71.3 \%)$ had been treated for less than 4 days, similar to another study in Sanglah Hospital. ${ }^{5}$

In conclusion, neonates with hyperbilirubinemia are predominantly male and preterm. However, normal birth weight, and vaginal delivery have the potential to develop hyperbilirubinaemia. Appropriate treatment may reduce total bilirubin levels to normal levels.

\section{References}

1. Mitra S, Rennie J. Neonatal jaundice: aetiology, diagnosis, and treatment. $\mathrm{Br} \mathrm{J}$ Hosp Med (London). 2017;78(12):699704

2. Martin CR, Cloherty JP. Neonatal hyperbilirubinemia. In Cloherty JP, Eichenwald EC, Stark AR. Manual of neonatal care. $5^{\text {th }}$ Ed. Philadelphia: Lippincolt Williams \& Wilkins; 2008. p. 
185-221.

3. Dewi AKS, Kardana IM, Suarta K. Efektivitas fototerapi terhadap penurunan kadar bilirubin total pada hiperbilirubinemia neonatal di RSUP Sanglah. Sari Pediatri. 2016;18(2):81-6.

4. Chime G, Egenede J, Arute J. Prevalence of neonatal jaundice on Central Hospital, Warri, Delta State, Nigeria. Int J Health Res. 2011;4(3):123-6.

5. Parwata WSS, Putra PJ, Kardana M, Artana WD, Sukmawati M. The characteristic of neonatal hyperbilirubinemia before and after phototherapy at Sanglah Hospital, Denpasar, Bali in 2017. Intisari Sains Medis. 2019;10(2):309-12.

6. 6. Rafie R, Nopiyanti A. Pengaruh berat badan lahir rendah terhadap ikterus neonatorum pada neonatus di Ruang Perinatologi RSUD Karawang Provinsi Jawa Barat tahun 2016. Jurnal Ilmu Kedokteran dan Kesehatan. 2017;4(1):12-17.

7. Faiqah S. Hubungan usia gestasi dan jenis persalinan dengan kadar bilirubinemia pada bayi ikterus Di RSUP NTB. Jurnal Kesehatan Prima. 2014;8(2):1355-62.

8. Fatmawati L, Sumiati S. Analisis faktorfaktor yang berhubungan dengan kejadian hiperbilirubin. Journals of Ners Community. 2017;8(1):11-9.

9. Windiarto $\mathrm{T}$, Yusuf $\mathrm{AH}$, Santoso AD, Nugroho S, Latifah S, Solih R, et al. Profil anak Indonesia 2018. Jakarta: Kementerian Pemberdayaan Perempuan dan Perlindungan Anak (KPPPA); 2018

10. World Health Organization. Health in the Sustainable Development Goals. India: World Health Organization; 2016

11. Nurani NB, Kadi FA, Rostini T. Incidence of neonatal hyperbilirubinemia based on their characteristics at Dr. Hasan Sadikin General Hospital Bandung Indonesia. Althea Medical Journal. 2017;4(3):431-4.

12. Auliasari NA, Etika R, Krisnana I, Lestari P.
Faktor risiko kejadian ikterus neonatorum. Pediomaternal Nursing Journal. 2019;5(2): 183-8.

13. Wijaya FA, Suryawan IWB. Faktor risiko kejadian hiperbilirubinemia pada neonatus di Ruang Perinatologi RSUD Wangaya Kota Denpasar. Medicina. 2019;50(2):357-64.

14. Cholifah, Djauharoh, Machfudloh $\mathrm{H}$. Faktor-faktor yang berpengaruh terhadap hiperbilirubinemia di RS Muhammadiyah Gersik. Midwiferia. 2017;3(1):14-25.

15. Hosea MK, Etika R, Lestari P. Hyperbilirubinemia treatment of neonatus in Dr. Soetomo Hospital Surabaya. Folia Medica Indonesiana. 2015;51(3):183-6.

16. Puteri IRP. Hubungan antara berat bayi lahir (BBL) dengan kejadian ikterik pada neonatus di Ruang Perinatologi RSUD Wonosari. Jurnal Kesehatan Ibu dan Anak Akademi Kebidanan An-Nur. 2017;2(2):918.

17. Madiastuti M, Chalada S. Faktor-faktor yang berhubungan dengan kejadian neonatus hiperbilirubin di RSB Pasutri Bogor Provinsi Jawa Barat tahun 2016. Jurnal Ilmu dan Budaya. 2017;40(55):6385-403.

18. Novianti N, Mediani HS, Nurhidayah I. Pengaruh field massage sebagai terapi adjuvan terhadap kadar bilirubin serum bayi hiperbilirubinemia. Jurnal Keperawatan Padjadjaran. 2017;5(3):31527.

19. Buthani VK, Committee on Fetus and Newborn. Phototherapy to prevent severe neonatal hyperbilirubinemia in the newborn infant 35 or more weeks of gestation. Pediatrics. 2011;128(4):e104652.

20. Bhethanabhotla S, Thukral A, Sankar MJ, Paul VK, Deorari AK. Effect of position of infant during phototherapy in management of hyperbilirubinemia in late preterm and term neonates: a randomized controlled trial. J Perinatol. 2013;33(10):795-9. 